\title{
MENINGKATKAN DISIPLIN BELAJAR MELALUI KONSEP DIRI SISWA
}

\author{
Ismatul Anwaroti ${ }^{1}$, Syafiq Humaisi ${ }^{2}$ \\ ${ }^{1}$ Institut Agama Islam Negeri Ponorogo, \\ ismaanwaroti082@gmail.com \\ ${ }^{2}$ Institut Agama Islam Negeri Ponorogo, \\ syafiqhumaisi@gmail.com
}

\begin{abstract}
Discipline is important in life to achieve success. However, the importance of the role of discipline in life is rarely paid attention, the results of observations of researchers in class VII I SMPN 2 Ponorogo show a lack of student discipline when learning is carried out, so the learning process becomes less effective. This is due to the low self-concept of students, they are not fully aware of their role as students. Self-concept can affect a person's behavior, because behavior is closely related to self-understanding. The test of this study was to determine the level of influence of self-concept on the learning discipline of grade VII students at SMPN 2 Ponorogo for the 2019/2020 academic year. The method used in this research is quantitative regression. The population in this study amounted to 286 students, with a cluster sampling technique of 32 students. The results showed that self-concept had an influence on learning discipline based on tcount of 4.114 and ttable 1.699 (then tcount> ttable), with a determination level of 34.7\%. Self-concept and learning discipline have a positive relationship, where if a student's self-concept (awareness) is high, then the student's learning discipline is also good, and vice versa if the student's self-concept is low, then the student is less disciplined in learning.
\end{abstract}

Keywords:Self Concept; Learning Dicipline.

\begin{abstract}
ABSTRAK
Disiplin menjadi hal yang penting dalam sebuah kehidupan untuk mencapai kesuksesan. Namun, pentingnya peranan disiplin dalam kehidupan jarang diperhatian, hasil observasi peneliti di kelas VII I SMPN 2 Ponorogo menunjukkan kurangnya disiplin siswa saat pembelajaran dilaksanakan, sehingga proses pembelajaran menjadi kurang efektif. Hal ini disebabkan rendahnya konsep diri yang dimiliki siswa, mereka kurang maksimal perannya sebagai pelajar. Konsep diri bisa berpengaruh pada tingkah laku seseorang, karena tingkah laku berkaitan erat dengan pemahaman diri. Tujian dari penelitian ini adalah untuk mengetahui tingkat pengaruh konsep diri terhadap disiplin belajar siswa kelas VII di SMPN 2 Ponorogo Tahun Pelajaran 2019/2020. Metode yang digunakan dalam penelitian ini adalah kuantitatif yang bersifat regresi. Populasi dalam penelitian ini berjumlah 286 siswa, dengan teknik pengambilan sampel cluster sampling yang berjumlah 32 siswa. Hasil penelitian menunjukkan konsep diri memiliki pengaruh terhadap disiplin belajar berdasarkan $t_{\text {hitung }}$ sebesar 4,114 dan $t_{\text {tabel }}$ 1,699 (maka $t_{\text {hitung }}>$ $t_{\text {tabel}}$ ), dengan kadar determinasi $34,7 \%$. Konsep diri dan disiplin belajar memiliki hubungan positif, dimana konsep diri (kesadaran) seorang siswa tinggi, maka disiplin belajar siswa juga baik, dan sebaliknya jika konsep diri siswa rendah, maka siswa kurang disiplin dalam belajar.
\end{abstract}

Kata kunci: Konsep diri; Disiplin belajar.

Copyright (c) 2020 Ismatul Anwaroti, Syafiq Humaisi 


\section{PENDAHULUAN}

Hasil survei peneliti yang dilakukan di kelas VII I SMPN 2 Ponorogo menunjukkan kurangnya disiplin siswa saat pembelajaran berlangsung, diantaranya sebagian dari mereka berbincang dengan temannya, mencontek tugas, tidak mengumpulkan tugas tepat waktu, dan sebagainya. Salah satu penyebab kurangnya disiplin siswa adalah kurangnya kesadaran siswa terhadap peran yang melekat pada diri mereka. Kesadaran diri disebut juga sebagai konsep diri. Mereka belum sepenuhnya menyadari perannya sebagai pelajar, hal ini juga dikarenakan rendahnya kemauan siswa untuk menwujudkan harapan atau cita-cita mereka. ${ }^{1}$

Menurut Vaughan dan Hogg konsep diri merupakan skema diri, yang meliputi pengetahuan seseorang tentang dirinya sendiri, yang berpengaruh dalam mengolah informasi, dan memutuskan tindakan. ${ }^{2}$ Konsep diri adalah gambaran diri, termasuk didalamnya persepsi seseorang tentang diri, perasaan, keyakinan, dan value yang berhubungan dengan pribadinya. Atwater mengartikan konsep diri merupakan sistem yang dinamis dan menyeluruh dari keyakinan seseorang mengenai dirinya sendiri, termasuk sikap, perasaan, nilai-nilai dan tingkah laku unik yang ada dalam diri individu. Cawagas menerangkan bahwa konsep diri mencakup pandangan seseorang terhadap dimensi fisiknya, ciri khas pribadinya, motivasi, kekurangan, kelebihan, dan sebagainya. ${ }^{3}$

Disiplin berperan penting dalam kesuksesan seseorang. Untuk mencapai kesuksesan, pendidikan menjadi alat untuk alat untuk membenuk pribadi manusia perlu diterapkan kedisiplinan. Manusia dapat mengontrol apa yang harus dilakukan dengan menjalani kehidupan yang teratur dan disiplin, oleh karena itu kedisiplinan harus ditanamkan dalam pribadi setiap peserta didik. ${ }^{4}$ Disiplin yaitu tingkah laku yang mentaati peraturan dan ketentuan yang sudah ditetapkan tanpa mengharap imbalan. Disiplin juga mengandung makna patuh terhadap pemimpin, perhatian dan pengendalian terhadap penggunaan waktu serta tanggung jawab pada apa yang sudah ditugaskan. ${ }^{5}$ Disiplin menjadikan anak menyadari apa yang dijadikan impian dan tidak dijadikan impian serta membantu mewujudkan

${ }^{1}$ Djaali, Psikologi Pendidikan, (Jakarta: Bumi Aksara, 2015), 132

${ }^{2}$ Eko A. Meinarno dan Sarlitio W. Sarwono, Psikologi Sosial, (Jakarta: Salemba Humanika, 2019), 66

${ }^{3}$ Desmita, Psikologi Perkembangan Peserta didik Panduan Bagi Orang Tua dan Guru dalam Memahami Psikologi Anak Usia SD, SMP, dan SMA, (Bandung: PT Remaja Rosdakarya, 2012), 163-164

${ }^{4}$ Masrur Hamam, "Pengaruh Motivasi Orang Tua Terhadap Kedisiplinan Santri Kelas V Madrasah Diniyah Ula Al-Muttaqin Desa Temboro Kec. Karas Kab. Magetan Tahun Pelajaran 2016/2017”, (Skripsi Sekolah Tinggi Agama Islam Ma’arif Magetan, 2016), 3

${ }^{5}$ Mohammad Mustari, Nilai-Nilai Karakter Refleksi Untuk Pendidikan, (Jakarta: PT Raja Grasindo Persada, 2014), 143 
impiannya. Disiplin dapat terbentuk jika didapatkan anak dari orang yang memberinya rasa aman dan cinta, bukan orang yang ditakuti dan berkuasa. ${ }^{6}$

Kebiasaan disiplin sangat perlu dilatih dan dibiasakan dalam kehidupan sehari-hari, sebab dengan kebiasaa disiplin manusia akan benar-benar terlatih dan dapat merasakan hidup yang berarti, manusia juga mendapatkan kepercayaan diri karena sikap disiplin dan tanggung jawab yang tinggi. Sikap disiplin yang kuat akan menimbulkan rasa tanggung jawab yang tingi dalam setiap kali melakukan tugas atau tanggung jawab kehidupan manusia itu sendiri. Maka, sangat penting bagi manusia agar selalu bersikap disiplin dalam setiap hal, yakni waktu, tugas, kewajiban, dan disiplin dalam berinteraksi.

Penelitian ini bertujuan untuk (1) Mengetahui tingkat konsep diri siswa kelas VII SMPN 2 Ponorogo, (2) Mengetahui tingkat disiplin belajar siswa kelas VII SMPN 2 Ponorogo, (3) Mengetahui tingkat pengaruh konsep diri terhadap disiplin belajar siswa pada mata pelajaran IPS kelas VII di SMPN 2 Ponorogo. Tujuan yang juga ingin diperoleh dari penelitian ini yakni diharapkan dapat berkontribusi atau bermanfaat dalam segi teoritis, yakni dalam menguatkan teori tentang teori pengaruh konsep diri terhadap disiplin belajar. Bermanfaat bagi sekolah sebagai bahan masukan tentang pentingnya konsep diri dalam meningkatkan disiplin belajar siswa, dan bermanfaat bagi guru dalam memecahkan masalah yang berhubungan dengan disiplin belajar dalam KBM, serta bermanfaat bagi peserta didik sendiri dalam melakukan evaluasi diri untuk memperbaiki dan meningkatkan kedisiplinan dalam belajar.

\section{METODE PENELITIAN}

Penelitian dilakukan di kelas VII Sekolah Menengah Pertama 2 Kota Ponorogo pada saat semester genap Tahun Pelajaran 2019/2020. Populasi dalam penelitian ini adalah seluruh siswa kelas VII yang berjumlah 286. Teknik dalam pengambilan sampel adalah cluster samplin, dimana pemilihan sampel merujuk pada suatu kelompok, yaitu kelas VII I di SMPN 2 Ponorogo yang berjumlah 32 siswa. Data yang digunakan dalam penelitian ini adalah data tentang konsep diri dan data tentang disiplin siswa kelas VII I SMPN 2 Ponorogo. Teknik dalam data menggunakan metode angket (kuisioner) berupa pertanyaan maupun pernyataan pengumpulan dengan 4 pilihan jawaban. Pilihan jawaban tersebut adalah (a) Selalu, (b) Sering, (c) Jarang, (d) Tidak pernah.

Model penelitian yang digunakan adalah model penelitian eksperimental, dengan menguji hipotesis dari hubungan sebab akibat dan peneliti ingin mengetahui seberapa besar pengaruh variabel independen terhadap variabel dependen. Variabel independen dalam penelitian ini adalah konsep diri, dan variabel dependennya adalah disiplin belajar. Pengambilan data dilakukan menggunakan metode angket. Sebelum instrumen digunakan, instrumen di uji

${ }^{6}$ Ibid., 147 
untuk mengetahui validitas dan reliabilitas. Variabel independennya adalah konsep diri, sedang variabel dependennya disiplin belajar. Penelitian ini menggunakan teknik analisis data deskriptif presentase untuk mengetahui tingkat konsep diri dan disiplin belajar siswa dan analisis regresi sederhana untuk mengetahui tingkat pengaruh konsep diri siswa terhadap disiplin belajar siswa.

1. Pengertian Konsep Diri dan Aspek Konsep Diri

Konsep diri merupakan gambaran yang dimiliki seseorang tentang dirinya sendiri mengenai perasaan, keyakinan, dan nilai-nilai yang berhubungan tentang dirinya. ${ }^{7}$ Konsep diri tidak dipengaruhi oleh faktor bawaan, tapi ia berkembang dari pengalaman yang didapatkan dari interaksi dengan lingkungan secara terus menerus dan terdiferensiasi. ${ }^{8}$

Kemampuan untuk melihat diri secara objektif ditandai dengan kemampuan untuk mempunyai wawasan tentang diri sendiri dan kemampuan untuk menangkap humor termasuk menjadikan dirinya sendiri sebagai sasaran. Misal, individu tidak marah jika dikritik dan disaat yang diperlukan ia bisa melepaskan diri dari dirinya sendiri dan meninjau dirinya sendiri sebagai orang lain. ${ }^{9}$

Menurut Agoes Dariyo konsep diri bersifat multi aspek, yaitu

a) Aspek fisiologis

Aspek ini berkaitan dengan fisik seseorang atau hal yang bersifat jasmaniah, karena tidak dapat dipungkiri penilaian orang lain terhadap diri seseorang dimulai dari apa yang mereka lihat, yakni fisik.

b) Aspek psikologis

Aspek psikologis mengandung unsur kognitif, afeksi, dan konasi. Pemahaman dan penghayatan unsur-unsur aspek psikologis tersebut akan mempengaruhi penilaian terhadap diri sendiri. Penilaian yang baik akan meningatan konsep diri yamg baik (positif self-concept), sebaliknya penilaian yang buruk akan mengembangkan konsep diri negatif (negative self-concept). Konsep diri pribadi, adalah cara seseorang dalam menilai kemampuan yang ada dan menggambarkan identitas dirinya.

c) Aspek Psiko-sosiologis

Konsep diri sosial merupakan persepsi, pikiran, perasaan, dan evaluasi seseorang terhadap kenderungan sosial yang ada pada dirinya sendiri, berkaitan dengan kapasitasnya dalam berhubungan dengan dunia diluar dirinya, perasaan mampu berharga dalam lingkup interaksi sosialnya.

d) Aspek psiko-spiritual

\footnotetext{
${ }^{7}$ Desmita, Psikologi Perkembangan (Bandung: PT Remja Rosdakarya, 2008),120.

${ }^{8}$ Hendriati Agustin, Psikologi Perkembangan Pendekatan Ekologi Kaitannya dengan Konsep Diri dan Penyesuaian Diri Remaja (Bandung: PT Refika Aditama, 2009), 138.
}

${ }^{9}$ Sarlito W Sarwono, Psikologi Remaja (Jakarta: PT Raja Grafindo Persada, 2011), 82. 
Kemampuan dan pengalaman individu berhubungan degan nilai-nilai dan ajaran agama. Aspek-aspek spiritual memiliki tiga unsur, yaitu beribadah, kesetiaan berdoa, dan berpuasa serta kesetiaan menjalankan ajaran agama. Diri yang berhubungan dengan aspek spiritual ini bersifat vertikal yang berarti keberadaan individu berhubungan erat dengan Tuhan. ${ }^{10}$

e) Aspek psikoetika dan moral

Konsep diri moral etik, berkaitan dengan persepsi, pikiran, perasaan, serta penilaian seseorang terhadap moralitas dirinya terkait dengan relasi personalnya dengan Tuhan, dan segala hal yang bersifat normatif, baik nilai maupun prinsip yang memberi arti dan arah kehidupan seseorang. ${ }^{11}$

2. Jenis Konsep Diri

Konsep diri dilihat kualitasnya ada dua, yaitu:

a. Konsep diri positif

Konsep diri positif memiliki ciri-ciri sebagai berikut:

1) Yakin akan kemampuan dirinya dalam mengatasi masalah

2) Merasa setara dengan orang lain

3) Menerima pujian tanpa rasa malu

4) Menyadari setiap orang mempunyai perasaan, keinginan, dan perilaku yang tidak seluruhnya diterima masyarakat

5) Mampu memperbaiki dirinya karena sanggup mengungkapkan aspekaspek kepribadian yang tidak disenangi dan berusaha mengubahnya.

b. Konsep diri negatif

Menurut William D. Brooks dan Philip Emmert terdapat empat ciri orang yang memiliki konsep diri negatif, yaitu:

1) Peka terhadap kritik

2) Responsif terhadap ujian

3) Merasa tidak disenangi orang lain

4) Bersikap pesimis terhadap kompetisi ${ }^{12}$

3. Pengertian Disiplin Belajar

Disiplin belahar berasal dari dua suku kata, disiplin dan belajar. Disiplin berarti pelatihan atau pengajaran. ${ }^{13}$ Belajar berarti proses berubahnya tingkah laku karena adanya pengalaman yang relatif menetap dan berorientasi pada

\footnotetext{
${ }^{10}$ Agoes Dariyo, Psikologi Perkembangan Anak Tiga Tahun Pertama (Psikologi Atitama), (Bandung, Refika Aditama, 2007), 202

${ }^{11}$ Alex Sobur, Psikologi Umum dan Lintasan Sejarah (Bandung: Pustaka Setia, 2003), 43 $129-130$

${ }^{12}$ Jalaludin Rakhmat, Psikologi Komunikasi, (Bandung: PT Remaja Rosdakarya, 2015),

${ }^{13}$ Ngainun Naim, Chararacter Buliding (Optimalisasi Peran Pendidikan Dalam Pengembangaan Ilmu dan Pembentukan Karakter Bangsa) (Jojakarta: Ar Ruzz Media, 2012), 142.
} 
kebaikan yang perubahannya bersifat positif-kualitatif. ${ }^{14}$ Disiplin belajar yaitu rangkaian sikap dan tingkah laku siswa sebagai wujud ketaatan dan kepatuhan untuk belajar dengan teratur baik saat di sekolah maupun tidak karena adanya kesadaran siswa itu sendiri, bukan karena paksaan. Sehingga senada dengan hasil riset yang menyatakan bahwa ketika sudah berdisiplin, maka anak dapat mengarahkan dirinya sendiritanpa pengaruh ataupun disuruh oleh orang lain. ${ }^{15}$ Fungsi disiplin belajar adalah untuk menerapkan cara belajar yang baik agar tercapai tujuan yang diinginkan siswa. ${ }^{16}$

Tujuan pelatihan disiplin itu sendiri adalah untuk membentuk siswa menjadi pribadi yang bertanggung jawab dan menciptakan situasi kegiatan belajar mengajar yang kondusif, tujuan ini pada dasarnya mencegah siswa dari kegagalan, dan meraih keberhasilan. ${ }^{17}$

4. Unsur-Unsur Disiplin

Harapan didiknya siswa secara disiplin adalah agar siswa berprilaku yang sesuai dengan standar yang telah ditetapkan dalam kelompok sosial yang ia tempati. Hurlock EB menjelaskan bahwa terdapat empat unsur yang ada dalam disiplin, yakni hukuman untuk siswa yang melanggar peraturan, peraturan sebagai landasan atau pedoman dalam berperilaku, penghargaan untuk siswa yang sudah berperilaku sesuai standar dan berkonsisten pada perilaku tersebut. ${ }^{18}$

5. Faktor Yang Mempengaruhi Disiplin Belajar

Disiplin terbentuk atas dasar beberapa faktor yang mempengaruhinya, yakni:

a. Faktor intern (terdapat dalam diri yang bersangkutan)

1) Faktor bawaan

John Brierly mengatakan keturunan dan lingkungan seseorang berpengaruh dalam menghasilkan setiap perilaku. Pendapat ini bermakna salah satu faktor yang menyebabkan orang bersikap disiplin adalah faktor bawaan yang merupakan warisan dari keturunannya.

2) Faktor kesadaran

Disiplin akan mudah dilakukan jika siswa memiliki kesadaran untuk selalu menaati dan mematuhi peraturan tanpa adanya pemaksaan.

3) Faktor minat dan motivasi

\footnotetext{
${ }^{14}$ Mohammad Mustari, Nilai Karakter Refleksi Untuk Pendidikan (Depok: PT Raja Grafindo Persada, 2019), 36.

${ }^{15}$ Nastiti Mufidah, Program Jam Wajib Belajar Dalam Membentuk Civic Disposition Warga Negara, HUMANIKA Journal, Vol. 23 No.1(2016), 39.

${ }^{16}$ Siti Ma'sunah, "Pengaruh Disiplin Belajar Terhadap Prestasi Belajar Siswa Kelas IV Sekolah Dasar Negeri Se- binaan II Kecamatan Petanahan Kabupaten Kebumen" (Skripsi, Universitas Negeri Semarang, 2015), 24-25. 1989), 108

${ }^{17}$ Soekarto Indra Fachrudin, Administrasi Pendidikan, (Tim Publikasi, FIB IKIP Malang,
}

${ }^{18}$ Hurlock EB, Perkembangan Anak,58 
Minat dan motivasi memiliki pengaruh yang kuat terhadap sesuatu yang diinginkan seseorang, jika siswa memiliki minat dan motivasi untuk bersikap disiplin, maka dengan sendirinya siswa akan berperilaku disiplin tanpa ada dorongan dari luar dirinya.

4) Faktor pengaruh pola pikir

Seseorang hendaknya selalu berpikir sebelum melakukan tindakan, jika siswa berpikir bahwa disiplin itu penting maka ia akan melakukan dengan sendirinya.

b. Faktor Ekstern

a) Contoh atau teladan

Teladan merupakan perbuatan seseorang yang berpengaruh dalam kehidupan seseorang, jika orang yang berpengaruh tersebut bersikap disiplin maka siswa akan meneladaninya atau meniru untuk bersikap disiplin.

b) Nasihat

Kata-kata yang didengar seorang siswa yang dipatuhinya akan memberikan pengaruh terhadap jiwanya, sehingga selain teladan nasihat juga dianggap perlu untuk mendisiplinkan siswa.

c) Faktor latihan

Latihan kedisiplinan yang baik dilakukan sejak anak masih kecil, supaya mereka terbiasa untuk melakukannya.

d) Faktor lingkungan

Faktor lingkungan juga bisa menunjang kedisiplinan seseorang, dalam lingkungan yang mnerapkan kedisiplinan yang ketat, seseorang akan terpaksa untuk melakukannya karena ia berada dalam lingkungan tersebut dan terikat dengan aturan yang berlaku.

e) Pengaruh kelompok

Faktor pembawaan dan latihan adalah faktor yang sangat berpengaruh dalam kedisiplinan, namun jika seorng tersebut tidak memegang prinsip disiplin dengan kuat dan hidup dalam kelompok yang tidak mementingkan disiplin, ia akan mudh terpengaruh dengan kelompok tersebut. Dan sebaliknya jika seseorang yang tidak mementingkan disiplin dan hidup dalam kelompok yang menegakkan disiplin ia akan terpengaruh positif dari kelompoknya. ${ }^{19}$

6. Dimensi Disiplin Belajar

Dalam konteks pembelajaran di sekolah ada beberapa bentuk kedisiplinan, diantaranya adalah:

1) Hadir di ruangan tepat pada waktunya

2) Tata pergaulan sekolah dengan warga sekolah

${ }^{19}$ Tulus Tu'u, Peran Disiplin Pada Perilaku dan Prestasi Siswa, (Jakarta: PT Grasindo,2018), 35-49 
3) Mengikuti kegiatan ekstrakulikuler

4) Belajar di rumah

7. Hubungan Konsep Diri Dengan Disiplin Belajar

Disiplin merupakan usaha untuk menjadikan seseorang tetap berada pada jalur sikap dan perilaku yang telah ditetapkan dalam suatu kelompok. Disiplin yaitu kondisi yang tercipta melalui rangkaian tingkah laku yang menunjukkan nilai teratur, patuh, tertib, dan kesetiaan. Sedang yang mempengaruhi disiplin adalah faktor intern dan faktor ekstern.

Konsep diri disebut juga kesadaran diri. Kesadaran diri akan muncul pada diri seseorang apabila ia memiliki gambaran tentang dirinya sendiri baik diketahui melalui orang lain maupun dari evaluasi diri. Gambaran bagaimana dia melihat kekuatan dan kelemahan dalam seluruh aspek kepribadiannya.

Hasil penelitian An Abdy Putra menunjukan terdapat pengaruh positif sebesar 57\% dengan nilai t 4,142. Sedang secara simultan konsep diri positif dan negatif terhadap disiplin belajar siswa kelas XI IPS di SMA Negeri 1 Kampar Timur sebesar 17,3\%, selebihnya ditentukan oleh variabel lain. Maka apabila konsep diri tinggi maka disiplin belajar siswa kelas XI IPS di SMAN 1 Kampar Timur juga tinggi. ${ }^{20}$

\section{HASIL DAN PEMBAHASAN}

Hasil penelitian terhadap siswa kelas VII di SMPN 2 Ponorogo tentang konsep diri dan disiplin belajar dapat dilihat di tabel dibawah ini:

Tabel 1.1 Skor konsep diri siswa kelas VII SMPN 2 Ponorogo

\begin{tabular}{|c|c|c|c|c|}
\hline No & Nilai & Frekuensi & Presentase & Kategori \\
\hline 1 & Lebih dari 32 & 6 & $19,355 \%$ & Tinggi \\
\hline 2 & $26-32$ & 19 & $61,290 \%$ & Sedang \\
\hline 3 & Kurang Dari 26 & 6 & $19,355 \%$ & Rendah \\
\hline \multicolumn{2}{|c|}{ Jumlah } & $\mathbf{3 1}$ & $\mathbf{1 0 0 \%}$ & \\
\hline
\end{tabular}

Dari tabel diatas dapat diketahui bahwa konsep diri siswa SMPN 2 Ponorogo yang berkategori tinggi sebanyak 6 responden $(19,35 \%)$, yang berkategori sedang berjumlah 19 responden (61,29\%), dan yang berkategori rendah berjumlah 6 responden $(19,35 \%)$. Maka secara umum konsep diri siswa SMPN 2 Ponorogo masuk dalam kategori sedang.

${ }^{20}$ An Ady Putra, "Pengaruh Konsep Diri Terhadap Disiplin Belajar Siswa Pada Mata Pelajaran Ekonomi di Sekolah Menengah Atas Negeri 1 Kampar Timur" (Skripsi, Universitas Islam Negeri Sultan Syarif Kasim Riau Pekan Baru, 2018), 93-94 
Tabel 1.2 Skor disiplin belajar siswa kelas VII SMPN 2 Ponorogo

\begin{tabular}{|c|c|c|c|c|}
\hline No & Skor & Frekuensi & Prosentase & Kategori \\
\hline 1 & Lebih dari 63 & 6 & $19,35 \%$ & Tingi \\
\hline 2 & 50 sampai dengan 63 & 20 & $64,52 \%$ & Sedang \\
\hline 3 & Kurang dari 50 & 5 & $16,13 \%$ & Rendah \\
\hline \multicolumn{2}{|l}{ Jumlah } & $\mathbf{3 1}$ & $\mathbf{1 0 0 \%}$ & \\
\hline
\end{tabular}

Berdasarkan pengkategorian pada tabel 4.6 dapat diketahui bahwa yang menyaakan disiplin belajar siswa dalam kategori tinggi dengan frekuensi 6 responden $(19,35 \%)$ dan dalam kategori sedang dengan frekuensi 20 responden $(64,52 \%)$, sedang kategori rendah dengan 5 responden (16,13\%), dengan demikian dapat diketahui secara umum disiplin beajar siswa SMPN 2 Ponorogo adalah sedang.

Uji regresi sederhana dilakukan untuk menguji pengaruh konsep diri siswa terhadap disiplin belajar siswa kelas VII di SMPN 2 Ponorogo dengan menggunakan SPSS Versi 25 untuk mengolah data. Berikut hasil perhitungannya:

Tabel 1.3 Hasil uji pengaruh konsep diri terhadap disiplin belajar siswa

\begin{tabular}{|c|c|c|c|c|c|c|}
\hline \multicolumn{7}{|c|}{ Coefficients $^{a}$} \\
\hline \multirow{2}{*}{\multicolumn{2}{|c|}{ Model }} & \multicolumn{2}{|c|}{ Unstandardized Coefficients } & $\begin{array}{l}\text { Standardized } \\
\text { Coefficients }\end{array}$ & \multirow[b]{2}{*}{$\mathrm{t}$} & \multirow[b]{2}{*}{ Sig. } \\
\hline & & B & Std. Error & Beta & & \\
\hline \multirow[t]{2}{*}{1} & (Constant) & 21,357 & 8,625 & & 2,476 & 019 \\
\hline & KONSEP DIRI & 1,201 & 292 & 607 & 4,114 &, 000 \\
\hline
\end{tabular}

Berdasarkan nilai $t_{\text {hitung }}$ sebesar 4,114 dan $t_{\text {tabel }}$ sebesar 1,699 maka $t_{\text {hitung }}>$ $\mathrm{t}_{\text {tabel }}$ sehinga $\mathrm{H}_{0}$ ditolak dan $\mathrm{H}_{1}$ diterima. Hal ini berarti bahwa untuk variabel konsep diri siswa secara parsial memiliki pengaruh terhadap disiplin belajar siswa. Dengan kata lain, apabila konsep diri siswa tinggi, maka disiplin belajar siswa juga tinggi. Sebaliknya, apabila konsep diri siswa rendah, maka disiplin belajar siswa juga akan rendah.

Tabel 1.4 Hasil analisis Koefisien determinasi

\begin{tabular}{|l|r|r|r|r|}
\hline \multicolumn{7}{|c|}{ Model Summary } \\
\hline Model & $\mathrm{R}$ & R Square & $\begin{array}{c}\text { Adjusted R } \\
\text { Square }\end{array}$ & $\begin{array}{c}\text { Std. Error of the } \\
\text { Estimate }\end{array}$ \\
\hline 1 &, $607^{\mathrm{a}}$ &, 368 &, 347 & 5,37630 \\
\hline
\end{tabular}


Dari tabel di atas diketahui koefisien determinasi adalah 0,347 artinya perubahan disiplin belajar mampu diterangkan oleh konsep diri (X) sebesar $34,7 \%$. Sementara sisanya $65,3 \%$ dipengaruhi oleh variabel lain diluar variabel yang diteliti. Hasil penelitian menunjukkan tingkat konsep diri dan disiplin belajar siswa kelas VII di SMPN 2 Ponorogo berada di tingkat sedang. Hal ini dikarenakan siswa kelas VII di SMP baru memasuki masa remaja dimana mereka belum menyadari penuh terhadap peran yang sedang dijalani dan hal ini berkaitan dengan evaluasi terhadap dirinya sendiri. Konsep diri ini akan memiliki pengaruh pada perilaku seseorang, karena periaku seseorang berhubungan dengan pemahaman terhadap dirinya sendiri.

Jika konsep diri memiliki pengaruh terhadap perilaku seseorang, maka artinya konsep diri juga memiliki pengaruh terhadap disiplin belajar siswa, yakni konsep diri menjadi faktor intern yang dapat mempengaruhinya. Karena dalam bersikap dan berprilaku siswa diharapkan dapat menerapkan kedisiplinan saat belajar baik ketika di sekolah, maupun dirumah. Namun, dari hasil penghitungan diketahui disiplin belajar siswa kelas VII di SMPN 2 Ponorogo berkategori sedang, hal ini dikarenakan emosi siswa yang masih labil dan usia mereka sedang transisi dari masa kanak-kanak menuju masa awal remaja. Sehingga memerlukan aturan yang tegas untuk melatih kedisiplinan mereka dalam belajar. Karena perilaku disiplin tercipta dari proses pembinaan keluarga, pendidikan, dan pengalaman siswa itu sendiri.

Berdasarkan hasil penelitian ini dapat diketahui terdapat pengaruh yang signifikan dan positif antara konsep diri terhadap disiplin belajar siswa kelas VII di SMPN 2 Ponorogo dengan koefisien determinasi 0,347 atau 34,7\%, artinya variabel konsep diri berkontribusi terhadap disiplin beajar siswa sebesar 34,7\% dan sisanya $65,3 \%$ dipengaruhi oleh variabel lain, selain variabel konsep diri.

\section{PENUTUP}

Berdasarkan hasil analisis data dan pembahasan, maka dapat disimpulkan bahwa: (1) Tingkat konsep diri siswa kelas VII di SMPN 2 Ponorogo berada dalam kategori sedang, karema siswa kelas VII baru menginjak masa remaja, dan belum mampu melakukan evaluasi terhadap dirinya sendiri dengan baik, (2) Disiplin belajar siswa kelas VII di SMPN 2 Ponorogo masuk dalam kategori sedang, karena siswa belum menyadari sepenuhnya terhadap peran yang sedang dijalankan, (3) ada pengaruh yang signifikan antara konsep diri terhadap disiplin belajar siswa kelas VII di SMPN 2 Ponorogo sebesar 34,7\%.

Berdasarkan hasil kesimpulan yang diperoleh, maka peneliti menyarankan agar 1) Siswa menanamkan konsep diri yang baik supaya pembelajaran IPS dapat dlakukan dengan sebaik mungkin 2) Guru memberikan pemahaman mengenai pentingnya disiplin, supaya tertanam konsep diri yang baik, 3) Peneliti selanjutnya yang tertarik dengan topik penelitian ini untuk mengembangkan dengan variabel lain, selain konsep diri. 


\section{DAFTAR PUSTAKA}

Ady Putra, An. (2018). Pengaruh Konsep Diri Terhadap Disiplin Belajar Siswa Pada Mata Pelajaran Ekonomi di Sekolah Menengah Atas Negeri 1 Kampar Timur. Skripsi. Universitas Islam Negeri Sultan Syarif Kasim Riau Pekan Baru.

Agustin, Hendriati. (2009). Psikologi Perkembangan Pendekatan Ekologi Kaitannya dengan Konsep Diri dan Penyesuaian Diri Remaja (p. 138). Bandung: PT Refika Aditama.

Dariyo, Agoes. (2007). Psikologi Perkembangan Anak Tiga Tahun Pertama (Psikologi Atitama). (p.202). Bandung, Refika Aditama.

Desmita. (2008). Psikologi Perkembangan (p.120). Bandung: PT Remja Rosdakarya.

Desmita. (2012. )Psikologi Perkembangan Peserta didik Panduan Bagi Orang Tua dan Guru dalam Memahami Psikologi Anak Usia SD, SMP, dan SMA. (p.163-164). Bandung: PT Remaja Rosdakarya.

Djaali. (2015). Psikologi Pendidikan, (p.132). Jakarta: Bumi Aksara.

Hamam, Masrur. (2016). Pengaruh Motivasi Orang Tua Terhadap Kedisiplinan Santri Kelas V Madrasah Diniyah Ula Al-Muttaqin Desa Temboro Kec. Karas Kab. Magetan Tahun Pelajaran 2016/2017 (p. 3).Skripsi. Sekolah Tinggi Agama Islam Ma'arif Magetan.

Indra Fachrudin, Soekarto. (1989). Administrasi Pendidikan. (p.108). Tim Publikasi, FIB IKIP Malang.

Ma'sunah, Siti. (2015). Pengaruh Disiplin Belajar Terhadap Prestasi Belajar Siswa Kelas IV Sekolah Dasar Negeri Se- binaan II Kecamatan Petanahan Kabupaten Kebumen". Skripsi. Universitas Negeri Semarang.

Meinarno, Eko A. dan Sarlitio W. Sarwono. (2019). Psikologi Sosial. (p.66). Jakarta: Salemba Humanika.

Mufidah, Nastiti, (2016). Program Jam Wajib Belajar Dalam Membentuk Civic Disposition Warga Negara, HUMANIKA Journal, Vol. 23 No.1

Mustari, Mohammad. (2019). Nilai Karakter Refleksi Untuk Pendidikan (p.36). Depok: PT Raja Grafindo Persada

Naim, Ngainun. (2012). Chararacter Buliding (Optimalisasi Peran Pendidikan Dalam Pengembangaan Ilmu dan Pembentukan Karakter Bangsa), (p.142). Jojakarta: Ar Ruzz Media.

Rakhmat, Jalaludin. (2015). Psikologi Komunikasi. (p.129-130). Bandung: PT Remaja Rosdakarya. 
Sobur, Alex. (2003) Psikologi Umum dan Lintasan Sejarah (p.43). Bandung: Pustaka Setia.

Tu'u, Tulus. (2018). Peran Disiplin Pada Perilaku dan Prestasi Siswa. (p. 35-49) Jakarta: PT Grasindo.

W Sarwono, Sarlito . (2011). Psikologi Remaja (p.82). Jakarta: PT Raja Grafindo Persada. 